\title{
Regulatory $T$ cell: key element in maintaining self-tolerance and homeostasis
}

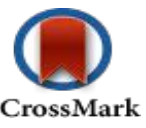

\author{
Tania Beatriz Romero- Adriàn ${ }^{1,2}$
}

${ }^{1}$ Graduate Studies in Immunology, Faculty of Medicine, University of Zulia, Maracaibo, Venezuela ${ }^{2}$ Institute of Biological Research, Faculty of Medicine, University of Zulia, Maracaibo, Venezuela

*Corresponding author: Tania Beatriz Romero- Adrian, Graduate Studies in Immunology, Institute of Biological Research, Faculty of Medicine, University of Zulia, 69 B Avenue, $77-49^{\text {th }}$ Streets, Panamericano Sector, Maracaibo, Venezuela. Tel: $+58-$ 0261-7532659; Fax: +58-0261-7533822; E-mail: corporacionbiomedica.alt@gmail.com

Received Date: November 23, 2015 Accepted Date: December 8, 2015 Published Date: December 10, 2015

Citation: Romero- Adrian, T.B., et al. Regulatory T cell: key element in maintaining self-tolerance and homeostasis. (2016) J Gastrointest Disord Liver Func 1(2): 34- 35.

\section{Introduction}

With the development of new technologies in the 1990s convincing evidences are presented in relation to the existence of immunosuppressive cells called Regulatory T cells ${ }^{[1]}$. These cells maintain self-tolerance and homeostasis (Figure 1).

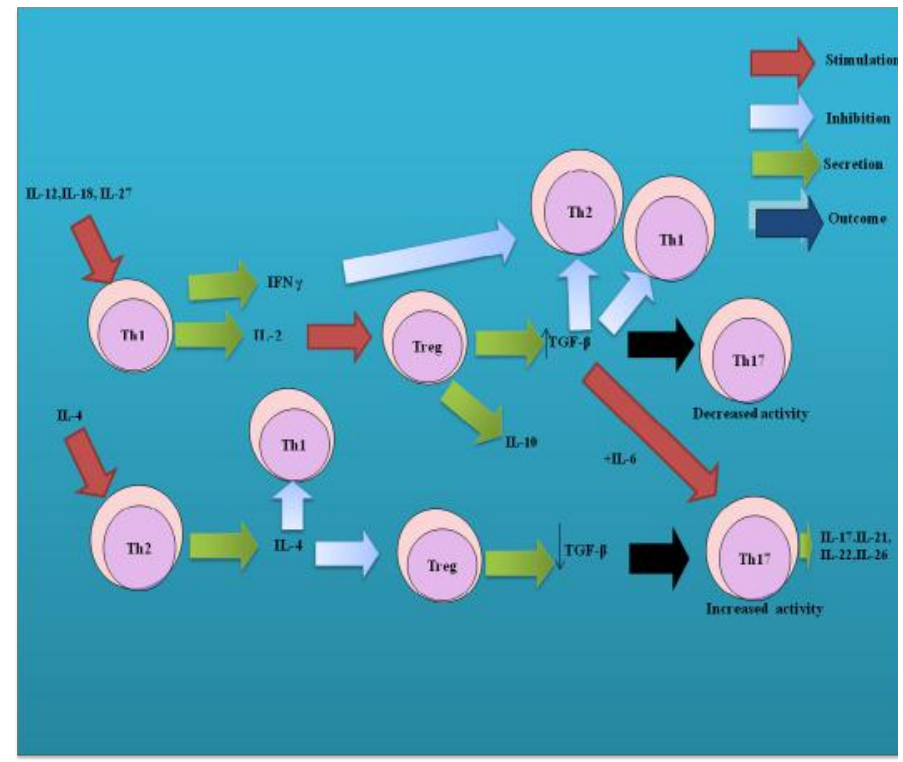

Figure 1: Treg cell and its connection with other cellular subpopulations through cytokines.

Th: T helper, Treg: Regulatory T cells, IL: Interleukin, IFN- $\gamma$ : Interferon- $\gamma$, TGF- $\beta$ : Transforming growth factor-beta
There are different subsets of Treg cells. CD4+CD25 $5^{\text {high }}$ Treg cells are the best-described subset. A key characteristic of CD4+CD25 ${ }^{\text {high }}$ Treg cells is its ability to induce anergy in vitro and suppress immune responses ${ }^{[2,3]}$. Some studies suggest that $\mathrm{CD} 4+\mathrm{CD} 25^{\text {high }}$ Treg cells inhibit proliferation of effector CD4+CD25- T cells and CD8+ T cells by arresting the proliferation of these cells at G1-S interphase of the cell cycle ${ }^{[4]}$. Recent data also indicate that $\mathrm{CD} 4+\mathrm{CD} 25^{\text {high }}$ Treg cells regulate through their cytokines to Th17 cells ${ }^{[5]}$. The total number of CD4+CD25 $5^{\text {high }}$ Treg cells in human peripheral blood increases with age, despite thymic involution ${ }^{[6]}$. Surface markers associated with CD4+CD2 $5^{\text {high }}$ Treg cells are of identification, homing/trafficking, activation/cell death and suppressive function. These cells have been classified into into natural (n) and inducible (i). The first originated in the thymus and the second coming of naive $\mathrm{T}$ cells. Natural Treg cells represent $5-10 \%$ of CD4+CD8- thymocytes in humans, mice, and rats ${ }^{[7]}$. Expression of the transcription factor forkhead box P3 (FOXP3) is considered a regulator of Treg development and function ${ }^{[8]}$.

When FOXP3 is defective or absent, it is present a recessive disorder immune dysregulation, polyendocrinopathy, enteropathy, X-linked (IPEX) syndrome the which is characterized by aggressive autoimmune manifestations that are usually fatal within the first 2 years of life, unless corrected via hematopoietic stem-cell transplantation ${ }^{[9,10]}$. Human ZAP70-deficient patients present a dramatic decrease in the frequency and number of tTregs ${ }^{[11]}$. Interestingly, CD4+ CD25+ tTregs were shown to frequently express two functional TCRs, in association with enhanced FOXP3 expression, suggesting that dual TCR expression 
may favor tTreg lineage commitment in humans ${ }^{[12]}$.

CD4+CD25 $5^{\text {high }}$ Treg cells participate in immune responses ${ }^{[13]}$ against malignant cells ${ }^{[14]}$ allogeneic organs, stemcell grafts ${ }^{[15]}$, infectious agents ${ }^{[16,17]}$ and celiac disease ${ }^{[18]}$. These cells are key part of the immune response in health and disease and possess properties of plasticity and interconvertibility under certain circumstances transforming into others phenotypes such as Th1, Th2 and Th17 by which they are located as a fundamental pillar in the immune response.

\section{References}

1. Sakaguchi, S., Sakaguchi, N., Asano, M., et al. Immunologic self-tolerance maintained by activated $\mathrm{T}$ cells expressing IL-2 receptor alpha-chains (CD25). Breakdown of a single mechanism of self-tolerance causes various autoimmune diseases. (2011) J Immunol 186(7): 3808-3821.

2.Annunziato, F., Cosmi, L., Liotta, F., et al. Phenotype, localization, and mechanism of suppression of CD4(+) CD25(+) human thymocytes. (2002) J Exp Med 196(3): 379-387.

3. Jonuleit, H., Schmitt, E., Kakirman, H., et al. Infectious tolerance: human $\mathrm{CD} 25(+)$ regulatory $\mathrm{T}$ cells convey suppressor activity to conventional CD4(+) T helper cells. (2002) J Exp Med 196(2): 255-260.

4. Adalid-Peralta, L., Fragoso, G., Fleury, A., et al. Mechanisms underlying the induction of regulatory $\mathrm{T}$ cells and its relevance in the adaptive immune response in parasitic infections. (2011) Int J Biol Sci 7(9): 1412-1426.

5. De la Rosa, M., Rutz, S., Dorninger, H., et al. Interleukin-2 is essential for CD4+CD25+ regulatory T cell function. (2004) Eur J Immunol 34(9): 2480-2488

6. Veldhoen, M., Hocking, R.J., Atkins, C.J., et al. TGFbeta in the context of an inflammatory cytokine milieu supports de novo differentiation of IL-17-producing T cells. (2006) Immunity 24(2): 179-189.
7. Gregg, R., Smith, C.M., Clark, F.J., et al. The number of human peripheral blood $\mathrm{CD} 4^{+} \mathrm{CD} 25^{\text {high }}$ regulatory $\mathrm{T}$ cells increases with age. (2005) Clin Exp Immunol 140(3): 540-546.

8. Wan, Y.Y., Flavell, R.A. How diverse- CD4 effector Tcells and their functions. (2009) J Mol Cell Biol 1(1): 20-36

9. Bennett, C.L., Christie, J., Ramsdell, F., et al. The immune dysregulation, polyendocrinopathy, enteropathy, X-linked syndrome (IPEX) is caused by mutations of FOXP3. (2001) Nat Genet 27: 20-21.

10. Seidel, M.G., Fritsch, G., Lion, T., et al. Selective engraftment of donor CD4+25high FOXP3-positive T cells in IPEX syndrome after nonmyeloablative hematopoietic stem cell transplantation. (2009) Blood 113(22): 5689-5691.

11.Poliani, P.L., Fontana, E., Roifman, C.M., et al. $\zeta$ Chain-associated protein of $70 \mathrm{kDa}$ (ZAP70) deficiency in human subjects is associated with abnormalities of thymic stromal cells: implications for T-cell tolerance. (2013) J Allergy Clin Immunol 131(2): 597-600.

12. Tuovinen, H., Salminen, J.T., Arstila, T.P. Most human thymic and peripheral-blood $\mathrm{CD}^{+} \mathrm{CD} 25^{+}$regulatory $\mathrm{T}$ cells express $2 \mathrm{~T}$-cell receptors. (2006) Blood 108(13): 4063-4070.

13. Romero- Adriàn, T.B., Leal - Montiel J. Helicobacter pylori infection: regulatory $\mathrm{T}$ cells and their participation in the immune response. (2013) Jundishapur Journal of Microbiology 6(4): e5183

14. Johnson, B.D., Jing, W., Orentas, R.J. CD25+ regulatory T cell inhibition enhances vaccine-induced immunity to neuroblastoma. (2007) J Immunother 30 (2): 203-214.

15. Xia, G., He, J., Zhang, Z., et al. Targeting acute allograft rejection by immunotherapy with ex vivo-expanded natural CD4+ CD25+ regulatory T cells. (2006) Transplantation 82(12): 1749-1755.

16. Romero-Adrián, T.B., Leal-Montiel, J., Monsalve-Castillo, F., et al. Helicobacter pylori: Bacterial factors and the role of cytokines in the immune response. (2010) Curr Microbiol 60(2): 143-155

17. Romero-Adriàn, T.B., Leal- Montiel. J., Fernández, G., et al. Role of cytokines and other factors involved in the mycobacterium tuberculosis infection. (2015) World J Immunol 5 (1): 16-50.

18. Granzotto, M., dal Bo, S., Quaglia, S., et al. Regulatory T-cell function is impaired in celiac disease. (2009) Dig Dis Sci 54(7): 1513-1519.
Ommega Publishers

Journal Title: Journal of Gastrointestinal Disorder \& Liver Function (JGDLF) Short name: J Gastro Dis Liver Func
ISSN No: 2471-0601

E-Mail Id: gastrology@ommegaonline.com Website: www.ommegaonline.org 